\title{
Refinement of the Region for Split Hand/Foot Malformation 5 on 2q31.1
}

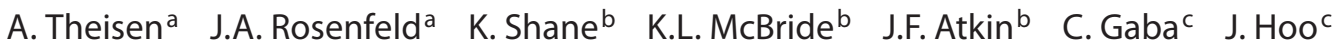

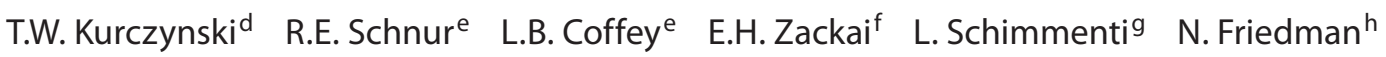

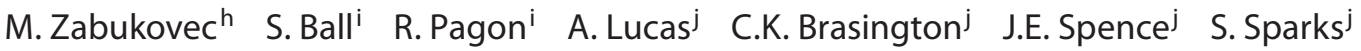

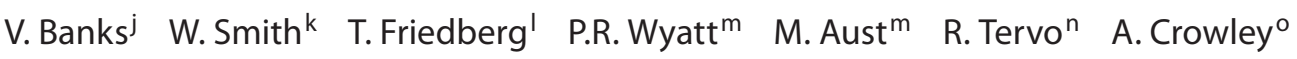 \\ D. Skidmore o, p A.N. Lamb ${ }^{\text {a }} \quad$ B. Ravnan ${ }^{\text {a }}$ T. Sahoo ${ }^{\text {a }} \quad$ R. Schultz ${ }^{\text {a }}$ B.S. Torchia ${ }^{\text {a }}$ M. Sgro ${ }^{a}$ \\ D. Chitayat' ${ }^{\prime}$ L.G. Shaffer ${ }^{\mathrm{a}}$
}

\begin{abstract}
a Signature Genomic Laboratories, Spokane, Wash., ${ }^{b}$ Nationwide Children's Hospital and The Ohio State University, Columbus, Ohio, 'Department of Pediatrics, University of Toledo Medical College \& NW Ohio Regional Genetics Center, Toledo, Ohio, d Genetics Center, Akron Children's Hospital, Akron, Ohio, e Division of Genetics, Department of Pediatrics, Cooper University Hospital/Robert Wood Johnson Medical School, Camden, N.J., ${ }^{f}$ Childrens Hospital of Philadelphia, Philadelphia, Pa., 9 Institute of Human Genetics, University of Minnesota, Minneapolis, Minn., ${ }^{h}$ Cleveland Clinic, Cleveland, Ohio, i Genetics Clinic, Yakima Valley Memorial Hospital, Yakima, Wash., jCarolinas Medical Center, Charlotte, N.C., ${ }^{k}$ Maine Medical Center/Maine Medical Partners Pediatric Specialty Care, Division of Genetics, Portland, Me., USA; 'The Prenatal Diagnosis and Medical Genetics Program, Mount Sinai Hospital, Toronto, Ont., ${ }^{m}$ York Central Hospital, Richmond Hill, Ont., Canada; ${ }^{\mathrm{n}}$ Gillette Children's Specialty Healthcare, St. Paul, Minn., USA; ${ }^{\circ}$ Maritime Medical Genetics, IWK Health Centre, and P Department of Pediatrics, Dalhousie University, Halifax, N.S., ${ }^{9}$ St. Michael Hospital, Toronto, Ont., Canada
\end{abstract}

\section{Key Words}

2q31.1 • DLX1/DLX2 - HOXD • Limb anomalies • Microdeletion $\cdot$ SHFM5

\begin{abstract}
Background: Deletions that encompass 2q31.1 have been proposed as a microdeletion syndrome with common clinical features, including intellectual disability/developmental delay, microcephaly, cleft palate, growth delay, and hand/ foot anomalies. In addition, several genes within this region have been proposed as candidates for split hand-foot malformation 5 (SHFM5). Methods: To delineate the genotypephenotype correlation between deletions of this region, we identified 14 individuals with deletions at 2q31.1 detected by microarray analysis for physical and developmental disabili-
\end{abstract}

ties. Results: All subjects for whom detailed clinical records were available had neurological deficits of varying degree. Seven subjects with deletions encompassing the HOXD cluster had hand/foot anomalies of varying severity, including syndactyly, brachydactyly, and ectrodactyly. Of 7 subjects with deletions proximal to the HOXD cluster, 5 of which encompassed $D L X 1 / D L X 2$, none had clinically significant hand/ foot anomalies. In contrast to previous reports, the individuals in our study did not display a characteristic gestalt of dysmorphic facial features. Conclusion: The absence of hand/ foot anomalies in any of the individuals with deletions of $D L X 1 / D L X 2$ but not the HOXD cluster supports the hypothesis that haploinsufficiency of the HOXD cluster, rather than $D L X 1 / D L X 2$, accounts for the skeletal abnormalities in subjects with 2q31.1 microdeletions.

Copyright $\odot 2011$ S. Karger AG, Basel

\section{KARGER}

Fax +4161306 1234

E-Mail karger@karger.ch

www.karger.com (c) 2011 S. Karger AG, Basel

$1661-8769 / 10 / 0015-0262 \$ 26.00 / 0$

Accessible online at:

www.karger.com/msy
Lisa G. Shaffer, $\mathrm{PhD}$

Signature Genomic Laboratories, 2820 N. Astor St.

Spokane, WA 99207 (USA)

Tel. +1 5094746840

E-Mailshaffer@signaturegenomics.com 
Over 30 interstitial deletions of the long arm of chromosome 2 have been reported [McConnell et al., 1980; Shabtai et al., 1982; Moller et al., 1984; Ramer et al., 1989; Wamsler et al., 1991; Boles et al., 1995; Chinen et al., 1996; Courtens et al., 1997; Nixon et al., 1997; Del Campo et al., 1999; Slavotinek et al., 1999; Maas et al., 2000; Bijlsma et al., 2005; Pescucci et al., 2007; Svensson et al., 2007; Zhao et al., 2007]. Although the breakpoints and clinical features vary among reported individuals, low birth weight, postnatal growth retardation, intellectual disability (ID)/ developmental delay (DD), microcephaly, mild facial dysmorphism (long eyelashes, downslanting palpebral fissures, micrognathia, low-set ears), and musculoskeletal anomalies appear to be characteristic for individuals with 2q deletions. Deletions encompassing 2q31.1 have been associated with various limb abnormalities ranging from mild digital abnormalities such as camptodactyly, 5th finger clinodactyly, syndactyly, duplicated halluces, and hypoplastic phalanges of $3 \mathrm{rd} / 4 \mathrm{th} / 5$ th finger to severe malformations such as split-hand/split-foot and monodactyly [Boles et al., 1995; Nixon et al., 1997; Goodman, 2002], although these severe malformations have been reported in only a few individuals with deletions of this region.

Disruptions of the $5^{\prime}$-end of the HOXD cluster (HOXD11-13) and neighboring genes on 2q31.1 have been implicated in limb malformations [Goodman et al., 2002]. The HOXD cluster is 1 of 4 highly conserved, homologous gene clusters coding for transcription factors with crucial roles in embryonic development. The cluster comprises 9 homologous genes: from proximal to distal they are HOXD13, HOXD12, HOXD11, HOXD10, HOXD9, HOXD8, HOXD4, HOXD3, and HOXD1 [Goodman, 2002]. Human homeobox EVX2 is located proximal to HOXD13 [D'Esposito et al., 1991], and proximal to EVX2 are 7 regulatory elements, R1-R7 [Goodman, 2002]. In mouse, expression of Hox genes is crucial for sonic hedgehog (Shh) transcription in the early developing limb bud. Mutations of HOXD13 have been associated with limb abnormalities [Goodman et al., 1998; Kan et al., 2003; Zhao et al., 2007]; the most common is an expansion of a polyalanine tract in exon 1 of HOXD13 reported to cause dominantly inherited synpolydactyly [Muragaki et al., 1996].

Based on genotype-phenotype correlations for individuals with deletions of the $2 \mathrm{q} 24.3 \mathrm{q} 31$ region and musculoskeletal anomalies, Duijf et al. [2003] proposed the region could be divided into 3 loci for limb abnormalities: individuals with 2q24.3 deletions have flexion deformities of the fingers, individuals with proximal $2 \mathrm{q} 31.1$ dele-

Genotype-Phenotype Correlation for

2q31.1 Deletions tions have a wide gap between the 1st and 2 nd toe, and distal 2q31.1 deletions that remove the HOXD10/HOXD13 and EVX2 genes, as well as mutations in HOXD13, cause synpolydactyly.

Goodman et al. [2002] identified a 117-kb microdeletion at the $5^{\prime}$-end of the HOXD cluster that removed HOXD9-13, EVX2, R1-R7, and part of a LINE element in a father and daughter with synpolydactyly. By genotypephenotype comparison with a girl with bilateral split foot and deletion of the entire HOXD cluster as well as the $5-\mathrm{Mb}$ region proximal to the cluster [Goodman et al., 2002], the authors suggested haploinsufficiency for the 5 '-HOXD cluster causes synpolydactyly, whereas the 5 -Mb interval proximal to EVX2 comprised a novel splithand/foot malformation locus, SHFM5 [Goodman et al., 2002].

The distal-less homeobox genes $D L X 1 / D L X 2$, which are within the candidate SHFM5 region, have been proposed as candidate genes for limb malformations. Expression studies of mouse homologs in vivo showed $D l x$ family members with a possible function in osteoclast and osteoblast formation as well as in mature osteoclasts; $D l \times 2$ is also expressed in less-mature osteoblasts [Li et al., 2008; Lezot et al., 2010]. Dlx2 is expressed in a subpopulation of osteoclasts in association with tooth, brain, nerve, and bone marrow volumetric growths and is also involved in the organization of cells that deposit tooth enamel in the labial region of molars during development [Lezot et al., 2008]. These data suggest a role for the Dlx1/ Dlx2 gene pair in the regulation of skeletal morphogenesis via functions within osteoclasts [Lezot et al., 2010]. However, heterozygous/homozygous knockouts of either or both genes show no limb abnormalities [Qiu et al., 1997], although null mutations of $D l x 2$ are lethal [Qiu et al., 1995].

Recently, Svensson et al. [2007] reported a female with $\mathrm{DD}$, microcephaly, and multiple upper- and lower-limb skeletal abnormalities including mild syndactyly of the 3rd/4th fingers, short middle phalanges, clinodactyly of the 5 th digit at the distal interphalangeal joint on both hands, symphalangism of metatarsal-phalengeal joints of the 2 nd/5th digits bilaterally, symphalangism of the $2 \mathrm{nd} / 3 \mathrm{rd} / 4$ th digits on both feet with fusion of the middle/ distal phalanges of the $2 \mathrm{nd} / 5$ th digits, and hallux valgus bilaterally. Oligonucleotide microarray analysis showed a 2.01-Mb deletion at 2q31.1, the distal breakpoint of which was $\sim 361 \mathrm{~kb}$ proximal to the HOXD cluster. The authors suggested the musculoskeletal phenotype in their subject may be caused by deletion of one or more of the regulatory elements upstream of HOXD. Despite the absence of 
limb abnormalities in mouse knockouts of either the Dlx1/ $D l x 2$ genes [Qiu et al., 1997], the study by Svensson et al. [2007] suggests that disruption of the region proximal to HOXD causes limb abnormalities of variable severity.

Several recent studies have proposed genotype-phenotype correlations for specific features associated with deletions at 2q31.1, including limb abnormalities [Mitter et al., 2010; Dimitrov et al., 2011]. In this study we report the molecular and clinical characterization of 14 individuals with deletions overlapping $2 \mathrm{q} 31.1$. This is the largest cohort to date of individuals with deletions of $2 \mathrm{q} 31.1$ characterized by microarray. Genotype-phenotype correlations among these individuals suggest regions upstream of the HOXD cluster can be excluded as candidates for SHFM5.

\section{Materials and Methods}

\section{Subject Ascertainment}

During the period encompassing March 2004 through February 2010, we tested 38,779 individuals submitted to Signature Genomics from the United States and abroad. The most common clinical presentations were ID, DD, or multiple congenital anomalies. Informed consent was obtained to publish photographs of the individuals described here.

Microarray-Based Comparative Genomic Hybridization

All 2q31.1 deletions were initially identified by microarraybased comparative genomic hybridization (aCGH) using various microarray platforms. Targeted BAC-based microarray analysis was originally performed on DNA from subjects $1,2,6,7,10$, and 11 using previously published methods [Bejjani et al., 2005]. DNA from patients $2-5$ and 7-9 was originally analyzed using wholegenome BAC-based microarray analysis as previously described [Ballif et al., 2008a]. Oligonucleotide-based microarray analysis was originally performed on DNA from patients 13 and 14, and DNA from patients 3 and 4 was re-analyzed using a 105K-feature whole-genome microarray (SignatureChip Oligo Solution v1.0, custom-designed by Signature Genomics, Spokane, Wash.; manufactured by Agilent Technologies, Santa Clara, Calif.) using previously described methods [Ballif et al., 2008b]. Oligonucleotidebased microarray analysis was originally performed on DNA from patient 12 , and DNA from patients $1,2,5,7,9$, and 11 was re-analyzed using a 12 -plex $135 \mathrm{~K}$-feature whole-genome oligonucleotide microarray (SignatureChip Oligo Solution v2.0, customdesigned by Signature Genomics, manufactured by Roche NimbleGen, Madison, Wisc.) according to previously described methods [Duker et al., 2010]. Subjects 6, 8, and 10 were re-analyzed using a custom $3 \times 720$ whole-genome oligonucleotide microarray according to the manufacturer's protocol (Roche NimbleGen). Results were displayed using custom software (Genoglyphix, Signature Genomics).

Fluorescence in situ Hybridization

Fluorescence in situ hybridization (FISH) was performed using $\mathrm{BAC}$ clones to visualize the deletions using previously de- scribed methods [Traylor et al., 2009]. The deletions in subjects 1-5 were confirmed by FISH using BAC probe CTD-2589O 4 from the DLX1/DLX2 locus on 2q31.1. BAC RP11-708G2 was used to confirm the deletion in subject 13, and BAC RP11-144D13 was used to confirm the deletion in subject 14 . For cases $6-8$ and $10-$ 12, BAC RP11-387A1 was used to confirm the deletion.

\section{Results}

\section{Molecular Analysis}

We identified 14 individuals with microdeletions encompassing $2 \mathrm{q} 31.1$. The deletions ranged in size from $124.5 \mathrm{~kb}$ to $16.49 \mathrm{Mb}$. The deletion in subjects $1-5$ encompassed the $D L X 1 / D L X 2$ loci, in 4 subjects it encompassed both the DLX1/DLX2 and HOXD cluster (patients 6-9), and in 3 subjects it encompassed only the HOXD cluster (patients 10-12). In patients 13 and 14 the deletions fell between the DLX and HOXD loci and did not delete either. Two of the deletions, including the smallest deletion in patient 12 and the deletion in patient 9, only deleted the 5 '-end of the HOXD cluster (fig. 1, table 1).

Thirteen of the 14 deletions were visualized by FISH which could not be performed on the DNA sample from subject 9. Parental FISH testing in 8 of the 14 subjects confirmed an apparently de novo origin (subjects 1-3, $5-7,10,11)$. Parental FISH testing for subject 13 showed the deletion was maternal in origin, and parental FISH testing for subject 14 showed the deletion was paternal in origin. Parental samples were unavailable for subjects 4 , 8 , and 9 (table 1).

Similar to the individuals reported by Dimitrov et al. [2011], no common breakpoints were identified in our subjects, and no mechanism of rearrangement could be delineated.

\section{Clinical Features}

Clinical characterization of the 14 individuals with deletions at $2 \mathrm{q} 31.1$ showed multiple common clinical features (table 1). All individuals, regardless of deletion size/ interval, had neurological deficits such as moderate to severe ID/DD, speech delay, hypotonia, seizures, asymmetric reflexes, dysmetria, and/or dystonia. A majority of subjects had short stature/growth delays, and most of the individuals displayed multiple dysmorphic features previously reported in individuals with deletions at 2q31.1, including brachycephaly, plagiocephaly, ptosis, downslanted palpebral fissures, microphthalmia, low-set ears, and parietal bossing. Of 7 individuals with deletions proximal to the HOXD cluster, none had clinically significant hand/foot anomalies (fig. 2). The remaining 7 in- 
Fig. 1. Schematic of deletions at $2 \mathrm{q} 31.1$ characterized by molecular cytogenetics in this and previous studies. Bars represent deletion sizes for the individuals. Green bars: deletions remove $D L X 1 / D L X 2$ but leave the HOXD gene cluster intact; blue bars: deletions remove $D L X 1 / D L X 2$ and the HOXD gene cluster; yellow bars: deletions remove the HOXD gene cluster but leave $D L X 1 / D L X 2$ intact; dusky pink bars: deletions leave $D L X 1 / D L X 2$ and the HOXD gene cluster intact. Dark blue boxes indicate genes described in the text.

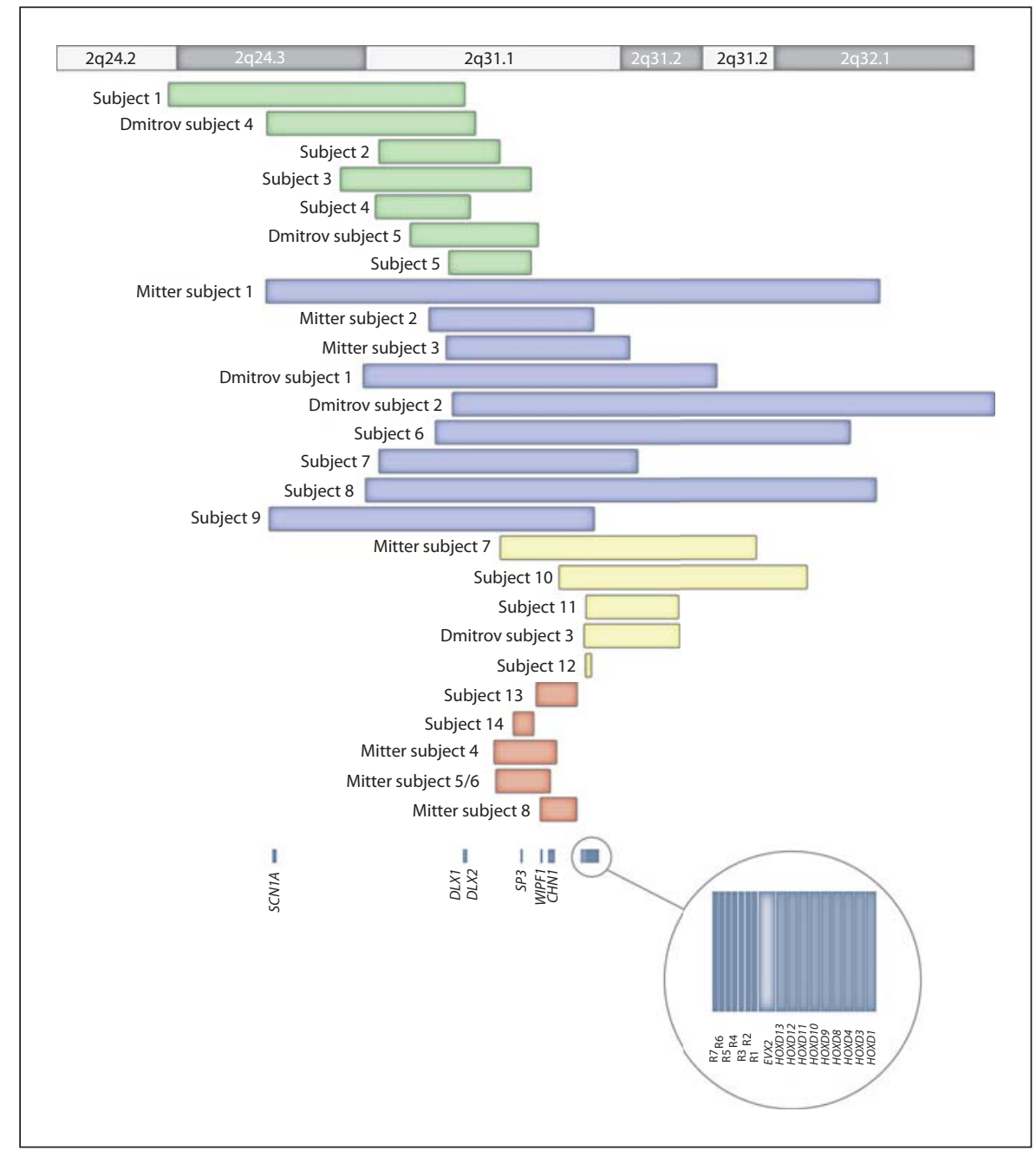

dividuals, whose deletions overlapped the HOXD cluster, had hand/foot anomalies of varying severity, including syndactyly, brachydactyly, and ectrodactyly (fig. 3).

\section{Discussion}

Several recent studies have proposed genotype-phenotype correlations for specific features associated with deletions at 2q31.1, including limb abnormalities [Mitter et al., 2010; Dimitrov et al., 2011]. Mitter et al. [2010] characterized 8 individuals with interstitial deletions at $2 \mathrm{q} 31.1$. Four individuals (patients $4-6,8$ ) had deletions that did not encompass either the DLX1/DLX2 or HOXD genes. No hand abnormalities were observed in patients 4-6, whereas mild foot anomalies were observed in patients 5, 6, and 8, such as long halluces and brachydactyly and/or syndactyly of the other toes. In addition, pa- tient 8 had sandal gap and syndactyly of the toes. The smallest region of overlap for all 8 deletions was $88 \mathrm{~kb}$ and encompassed 1 known gene, WIPF1. The authors suggested, based on the function of WIPF1, that haploinsufficiency of this gene alone was unlikely to be responsible for the variable features associated with 2 q31.1 deletions and that haploinsufficiency of multiple genes in the region would likely be necessary to result in the anomalies. The authors proposed that disruption of the DLX1/DLX2 genes may be responsible for the craniofacial dysmorphism, the HOXD cluster for the limb and genital anomalies, $C H N 1$ for the ocular phenotype, $S P 3$ for the cardiac anomalies, and DLX1/DLX2 and CHN1 for the neurological features [Mitter et al., 2010].

Recently, Dimitrov et al. [2011] characterized 5 individuals with interstitial deletions at $2 \mathrm{q} 31.1$ using a BAC microarray. Two subjects with mild limb abnormalities had deletions that encompassed the HOXD cluster and 
Table 1. Summary of clinical features of 14 individuals with interstitial deletions encompassing $2 \mathrm{q} 31.1$

\begin{tabular}{|c|c|c|c|c|c|c|c|}
\hline Study subject: & 1 & 2 & 3 & 4 & 5 & 6 & 7 \\
\hline Age & 3 years & $\begin{array}{l}8 \text { years } \\
9 \text { months }\end{array}$ & 4 years & $\begin{array}{l}6 \text { years } \\
11 \text { months }\end{array}$ & $\begin{array}{l}4 \text { years } \\
8 \text { months }\end{array}$ & $\begin{array}{l}29 \text { years } \\
3 \text { months }\end{array}$ & 6 years \\
\hline Array type & $135 \mathrm{~K}$ oligo & 135K oligo & 105K oligo & 105K oligo & 135K oligo & $720 \mathrm{~K}$ oligo & 135K oligo \\
\hline $\begin{array}{l}\text { Min. deletion coor- } \\
\text { dinates (chr2, hg18) }\end{array}$ & $\begin{array}{l}163,190,357-172, \\
706,485\end{array}$ & $\begin{array}{l}166,519,354- \\
173,745,491\end{array}$ & $\begin{array}{l}168,702,606- \\
174,842,496\end{array}$ & $\begin{array}{l}169,823,689-172 \\
870,083\end{array}$ & $\begin{array}{l}172,190,180-174 \\
860,186\end{array}$ & $\begin{array}{l}171,777,874-185 \\
147,758\end{array}$ & $\begin{array}{l}163,942,689- \\
182,115,376\end{array}$ \\
\hline DLX1/2 deleted & + & + & + & + & + & + & + \\
\hline HOXD deleted & - & - & - & - & - & + & + \\
\hline Inheritance & $\mathrm{dn}$ & $\mathrm{dn}$ & $\mathrm{dn}$ & unknown & $\mathrm{dn}$ & $\mathrm{dn}$ & $\mathrm{dn}$ \\
\hline Height & $\begin{array}{l}89 \mathrm{~cm} \\
(<5 \text { th centile })\end{array}$ & NA & $<3$ rd centile & NA & $\begin{array}{l}100 \mathrm{~cm} \\
(5 \text { th centile) }\end{array}$ & Progressive short stature & NA \\
\hline Weight & $\begin{array}{l}12.5 \mathrm{~kg} \\
(<5 \text { th centile })\end{array}$ & NA & $<3$ rd centile & NA & $\begin{array}{l}14.5 \mathrm{~kg} \\
\text { (3rd centile) }\end{array}$ & NA & NA \\
\hline $\begin{array}{l}\text { Head } \\
\text { circumference }\end{array}$ & $\begin{array}{l}46.5 \mathrm{~cm} \\
(<5 \text { th centile })\end{array}$ & NA & 10-25th centile & NA & $\begin{array}{l}48.5 \mathrm{~cm} \\
(2 \mathrm{nd} \text { centile })\end{array}$ & Microcephalic & NA \\
\hline Neurological & $\begin{array}{l}\mathrm{DD} \text {, intractable } \\
\text { seizures, severe ID, } \\
\text { hypotonia, atrophy, } \\
\text { poor myelination }\end{array}$ & Epilepsy & $\begin{array}{l}\text { Hypotonia, } \\
\text { DD, speech } \\
\text { delay }\end{array}$ & $\begin{array}{l}\text { Hypotonia, } \\
\text { severe DD, } \\
\text { speech delay }\end{array}$ & $\begin{array}{l}\text { DD, speech delay, } \\
\text { inattention, hypotonia }\end{array}$ & DD, seizure disorder & Seizures, DD \\
\hline Eyes & $\begin{array}{l}\text { Abnormal VER, } \\
\text { cortical visual loss }\end{array}$ & $\mathrm{NL}$ & NL & $\begin{array}{l}\text { Small angle } \\
\text { esotropia s/p } \\
\text { repair, nystagmus }\end{array}$ & $\mathrm{NL}$ & $\mathrm{NL}$ & Coloboma \\
\hline $\begin{array}{l}\text { Dysmorphic } \\
\text { features }\end{array}$ & $\begin{array}{l}\text { Hypertelorism, } \\
\text { downslanted } \\
\text { palpebral fissures, } \\
\text { left ear pits }\end{array}$ & $\mathrm{NL}$ & $\begin{array}{l}\text { Ptosis, } \\
\text { short nose, } \\
\text { short midface }\end{array}$ & $\begin{array}{l}\text { Plagiocephaly, } \\
\text { underbite }\end{array}$ & $\begin{array}{l}\text { Prominent forehead, } \\
\text { short downslanting } \\
\text { palpebral fissures, } \\
\text { thin alar base, bilateral } \\
\text { renal enlargement }\end{array}$ & NL & $\begin{array}{l}\text { Micro- } \\
\text { phthalmia }\end{array}$ \\
\hline Musculoskeletal & NL & $\mathrm{NL}$ & NL & Wears AFOs & Possible hip dysplasia & $\mathrm{NL}$ & NL \\
\hline Hands/feet & NL & $\mathrm{NL}$ & NL & $\begin{array}{l}\text { Overlapping toes, } \\
\text { flat arches, slender } \\
\text { long fingers/toes, } \\
\text { mild/moderate } \\
\text { hyperextensibility } \\
\text { of most joints }\end{array}$ & NL & $\begin{array}{l}\text { Oligodactyly, } 2 \text { digits on } \\
\text { right hand, } 2 \text { or } 3 \text { ulnar } \\
\text { sides of metacarpals are } \\
\text { missing, 5th finger } \\
\text { clinodactyly on left hand, } \\
\text { cutaneous syndactyly } \\
\text { between 2nd and 3rd toes } \\
\text { bilaterally }\end{array}$ & Ectrodactyly \\
\hline Cardiovascular & NL & NA & NA & NL & NA & NL & NA \\
\hline Genitourinary & NL & $\mathrm{NL}$ & NL & $\mathrm{NL}$ & $\mathrm{NL}$ & $\mathrm{NL}$ & $\mathrm{NL}$ \\
\hline Other & $\begin{array}{l}\text { Autonomic } \\
\text { dysfunction with } \\
\text { neurogenic bladder } \\
\text { and GI dysmotility }\end{array}$ & & & Severe bruxism & & & $\begin{array}{l}\text { Teeth miss- } \\
\text { ing, hearing } \\
\text { loss, G-tube }\end{array}$ \\
\hline
\end{tabular}

AFOs = Ankle-foot orthotics; $\mathrm{dn}=$ de novo; GD = growth delay; GI = gastrointestinal; $\mathrm{ID}=$ intellectual disability; mat. = maternally inherited; $\mathrm{MCP}=$ metacarpophalangeal; $\mathrm{NA}=$ not available; $\mathrm{NL}=$ normal; pat. = paternally inherited; $\mathrm{ROM}=$ range of motion; VER = visual evoked response. 


\begin{tabular}{|c|c|c|c|c|c|c|}
\hline 8 & 9 & 10 & 11 & 12 & 13 & 14 \\
\hline $\begin{array}{l}17 \text { years } \\
3 \text { months }\end{array}$ & 6 months & $\begin{array}{l}7 \text { years } \\
6 \text { months }\end{array}$ & 19 months & $\begin{array}{l}14 \text { years } \\
8 \text { months }\end{array}$ & $\begin{array}{l}3 \text { years } \\
4 \text { months }\end{array}$ & $\begin{array}{l}14 \text { years } \\
8 \text { months }\end{array}$ \\
\hline $720 \mathrm{~K}$ oligo & 135K oligo & $720 \mathrm{~K}$ oligo & 135K oligo & $135 \mathrm{~K}$ oligo & 105K oligo & 105K oligo \\
\hline $\begin{array}{l}169,521,432-186 \\
004,985\end{array}$ & $\begin{array}{l}166,422,383-176 \\
872,179\end{array}$ & $\begin{array}{l}175,712,131-183 \\
736,599\end{array}$ & $\begin{array}{l}176,578,119-180, \\
521,091\end{array}$ & $\begin{array}{l}176,556,102-176 \\
681,541\end{array}$ & $\begin{array}{l}174,988,738-176 \\
362,909\end{array}$ & $\begin{array}{l}174,366,202-174 \\
971,985\end{array}$ \\
\hline+ & + & - & - & - & - & - \\
\hline+ & partial & + & + & partial & - & - \\
\hline unknown & unknown & $\mathrm{dn}$ & dn & unknown & mat. & pat. \\
\hline Short stature & $\begin{array}{l}63 \mathrm{~cm} \\
(10-25 \text { th centile })\end{array}$ & $\begin{array}{l}115.6 \mathrm{~cm} \\
\text { (3rd centile) }\end{array}$ & $\begin{array}{l}75.6 \mathrm{~cm} \\
\text { (15th centile) }\end{array}$ & Short stature & NA & $\begin{array}{l}170.6 \mathrm{~cm} \\
\text { (63rd centile) }\end{array}$ \\
\hline NA & $\begin{array}{l}5.92 \mathrm{~kg} \\
\text { (5-10th centile) }\end{array}$ & $\begin{array}{l}32.1 \mathrm{~kg} \\
\text { (75th-90th centile) }\end{array}$ & $\begin{array}{l}10.2 \mathrm{~kg} \\
\text { (20th centile) }\end{array}$ & NA & NA & $\begin{array}{l}76.6 \mathrm{~kg} \\
\text { (93rd centile) }\end{array}$ \\
\hline Microcephalic & $\begin{array}{l}41 \mathrm{~cm} \\
\text { (25th centile) }\end{array}$ & $\begin{array}{l}48.25 \mathrm{~cm} \\
(<2 \text { nd centile })\end{array}$ & $\begin{array}{l}43.2 \mathrm{~cm} \\
(<3 \mathrm{rd} \text { centile })\end{array}$ & NA & NA & $\begin{array}{l}54 \mathrm{~cm} \\
\text { (50th centile) }\end{array}$ \\
\hline $\begin{array}{l}\text { Severe DD, increased } \\
\text { tone in lower extremities } \\
\text { with brisk deep tendon } \\
\text { reflexes }\end{array}$ & Hypotonia, DD & $\begin{array}{l}\text { DD, delayed speech/ } \\
\text { speech apraxia, his- } \\
\text { tory of febrile seizures, } \\
\text { hypotonia, asymmet- } \\
\text { ric reflexes, dysmetria, } \\
\text { poor balance }\end{array}$ & Hypotonia & $\begin{array}{l}\text { DD, dystonia, } \\
\text { dysmetria }\end{array}$ & NA & $\begin{array}{l}\text { DD, slightly clumsy, } \\
\text { mild hypotonia } \\
\text { (now resolved), mild } \\
\text { cerebellar hypoplasia } \\
\text { prenatally (not con- } \\
\text { firmed postnatally) }\end{array}$ \\
\hline $\begin{array}{l}\text { Significant blepharo- } \\
\text { phimosis, difficulty } \\
\text { abducting both eyes }\end{array}$ & NL & $\begin{array}{l}\text { Nystagmus, photo- } \\
\text { phobia, esotropia/ } \\
\text { exotropia, poor visual } \\
\text { motor coordination }\end{array}$ & NL & NL & NL & NL \\
\hline Distinctive facial features & $\begin{array}{l}\text { Sparse hair, } \\
\text { brachycephaly, } \\
\text { parietal bossing }\end{array}$ & $\begin{array}{l}\text { Mild hypotelorism, } \\
\text { narrow inner canthal } \\
\text { distance, synophrys, } \\
\text { bilateral ptosis, down- } \\
\text { slanting palpebral } \\
\text { fissures, low-set ears }\end{array}$ & Protuberant eyes & NL & NL & $\begin{array}{l}\text { Deep-set eyes, } \\
\text { prominent supra } \\
\text { orbital ridges }\end{array}$ \\
\hline Significant kyphosis & $\begin{array}{l}\text { Subluxation of } \\
\text { 1st MCP joints } \\
\text { bilaterally }\end{array}$ & $\begin{array}{l}\text { Leg length discrep- } \\
\text { ancy, mild scoliosis }\end{array}$ & NL & $\begin{array}{l}\text { Joint contractures, } \\
\text { decreased ROM at } \\
\text { MCP bilaterally }\end{array}$ & NL & NL \\
\hline $\begin{array}{l}\text { Camptodactyly of all } \\
\text { digits with syndactyly of } \\
\text { toes } 2+3 \text { and short } 4 \text { th } \\
\text { and } 5 \text { th toes bilaterally }\end{array}$ & $\begin{array}{l}\text { 4th toes overlapping } \\
3 \mathrm{rd} / 5 \text { th toes, } \\
\text { partial syndactyly } \\
\text { of } 2 \mathrm{nd} / 3 \mathrm{rd} \text { toes }\end{array}$ & $\begin{array}{l}\text { Brachydactyly, } \\
\text { mild ectrodactyly, } \\
\text { contracted thumbs }\end{array}$ & $\begin{array}{l}\text { Bilateral clinodactyly } \\
\text { with bridge or deep- } \\
\text { set single palmar } \\
\text { creases, } 2-3 \text { syndac- } \\
\text { tyly, widening at } \\
\text { distal toes }\end{array}$ & $\begin{array}{l}\text { Syndactyly of right } \\
4 \text { th/5th toes, brachy- } \\
\text { dactyly of left } 5 \text { th toe, } \\
\text { abnormal X-rays of } \\
\text { left/right feet }\end{array}$ & NL & $\begin{array}{l}\text { Small persistent fetal } \\
\text { pads and slight } \\
\text { increase in mobility }\end{array}$ \\
\hline NA & NA & $\begin{array}{l}\text { Bicuspid valves, } \\
\text { mild hypertension }\end{array}$ & NA & NA & NA & NL \\
\hline \multirow[t]{2}{*}{ NL } & $\begin{array}{l}\text { Hypoplasia of labia } \\
\text { minora, proximally } \\
\text { inserted anus }\end{array}$ & NL & NL & NL & NL & NL \\
\hline & Cleft palate & Chronic constipation & & & & \\
\hline
\end{tabular}



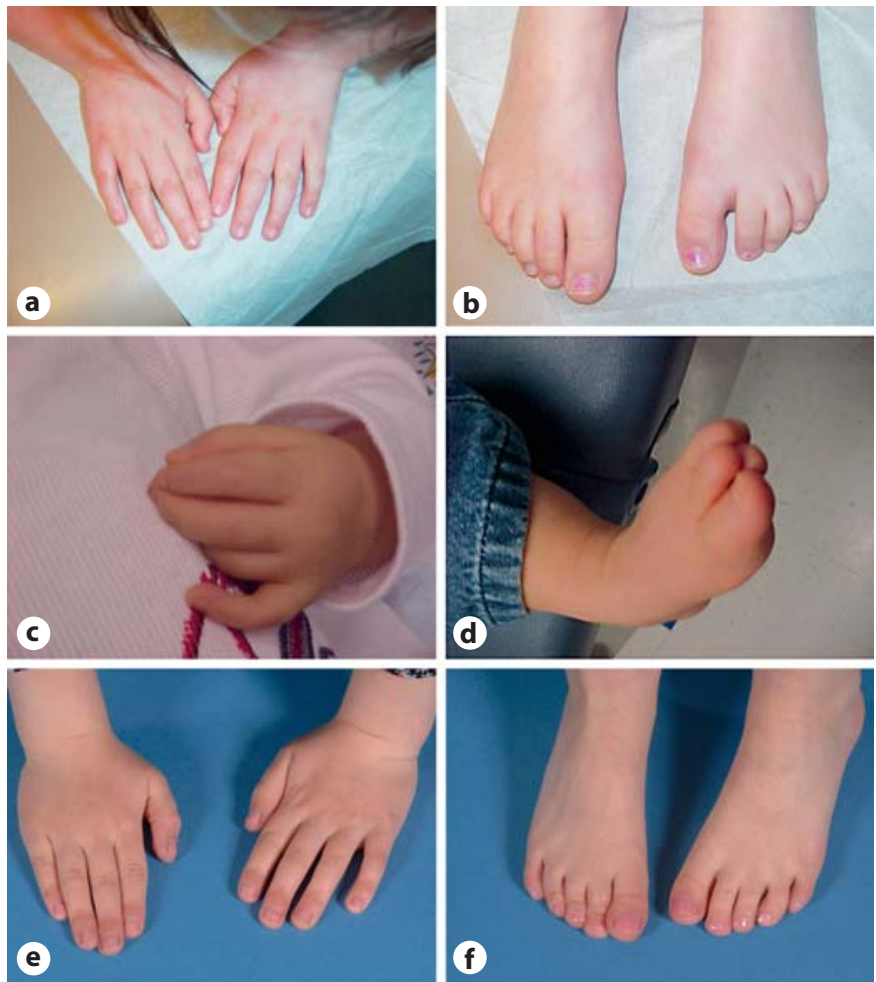

Fig. 2. Hand and foot images of individuals with deletions at $2 \mathrm{q} 31.1$ that do not encompass the HOXD gene cluster. a, b Subject 2. c, d Subject 4. Note long, slender fingers and overlapping toes. e, f Subject 5 .

$D L X 1 / D L X 2,1$ subject with mild limb abnormalities had a deletion that left $D L X 1 / D L X 2$ intact, and in 2 subjects with no limb abnormalities, the deletion left HOXD intact. The authors suggested a critical limb abnormality locus spanning from $1.5 \mathrm{Mb}$ centromeric to $1 \mathrm{Mb}$ telomeric of the HOXD gene cluster.

Although the $5-\mathrm{Mb}$ region proximal to EVX2 has been proposed as a locus for SHFM5, our results suggest otherwise. In our cohort, only the 7 individuals with deletions that encompassed at least the $5^{\prime}$-end of the HOXD cluster had hand/foot anomalies of varying severity, including syndactyly, brachydactyly, and ectrodactyly. Of the 7 individuals with deletions proximal to the HOXD cluster, none had clinically significant hand/foot anomalies. Subject 1 (distal breakpoint: $172.7 \mathrm{Mb}$ ), subject 3 (distal breakpoint: $174.8 \mathrm{Mb}$ ), and subject 5 (distal breakpoint: $174.9 \mathrm{Mb}$ ) have normal hands/feet, and subject 4 (distal breakpoint: 172.9 Mb) was reported to have only overlapping toes, flat arches, slender and long fingers/ toes, and mild/moderate hyperextensibility. Therefore,
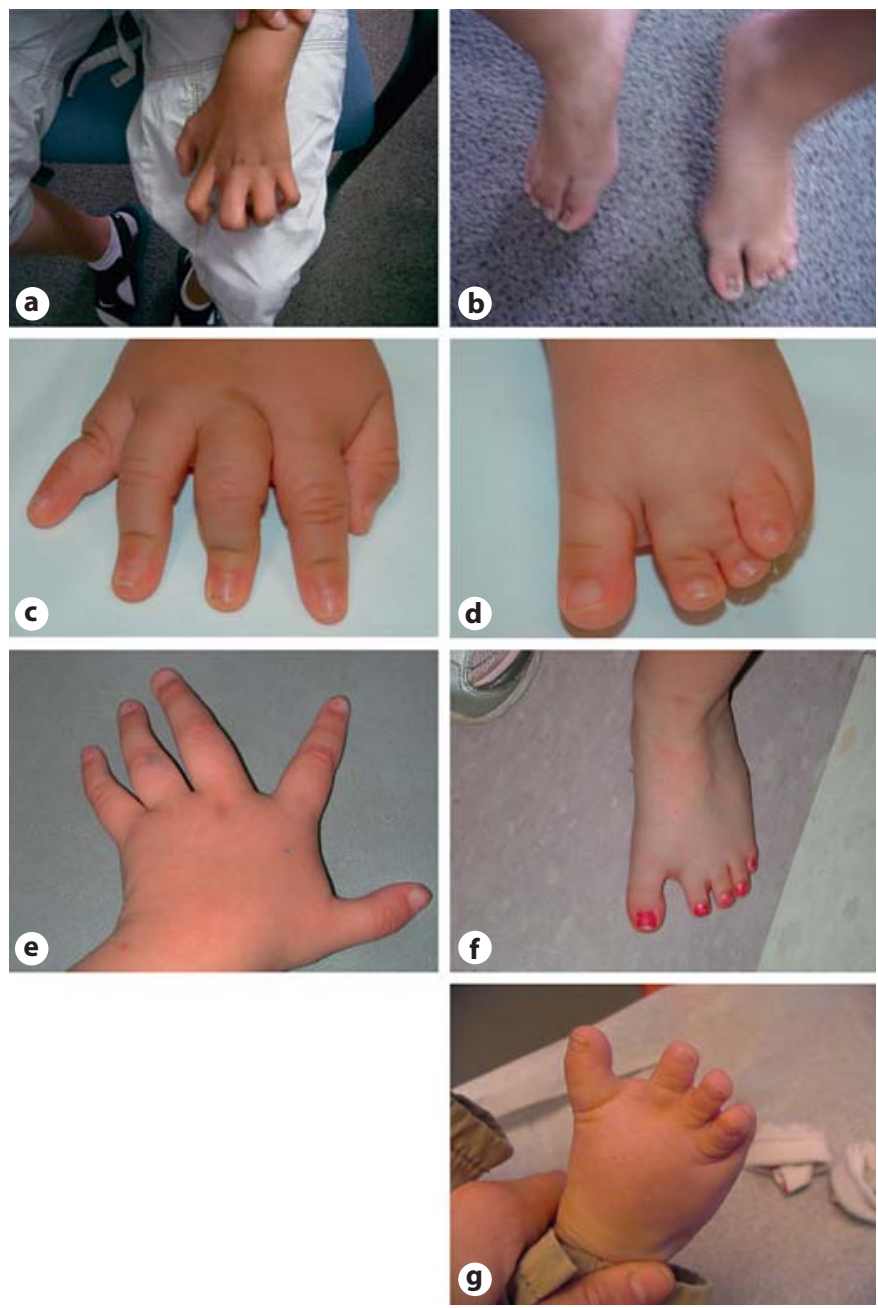

Fig. 3. Hand and foot images of individuals with deletions at 2q31.1 that encompass the HOXD gene cluster. Left hand (a) and feet (b) of subject 8 . Note camptodactyly of all digits with syndactyly of toes 2 and 3 and short 4th and 5th toes bilaterally. Right hand (c) and left foot (d) of subject 9. Note 4th toe overlapping $3 \mathrm{rd} / 5$ th toes and partial syndactyly of $2 \mathrm{nd} / 3 \mathrm{rd}$ toes. Left hand (e) and left foot (f) of subject 10. Note brachydactyly, mild ectrodactyly, and contracted thumbs. $\mathbf{g}$ Left foot of subject 11 . Note syndactyly of toes 2 and 3 and widening at distal toes.

the region $5^{\prime}$ of the HOXD cluster, including DLX1/DLX2, is unlikely to be the SHFM5 locus. Furthermore, 2 of the individuals, subjects 13 and 14 , have microdeletions that lie entirely between $D L X 1 / D L X 2$ and the HOXD cluster; the distal breakpoints are $290.2 \mathrm{~kb}$ and $\sim 1.68 \mathrm{Mb}$ proximal of EVX2, respectively. Both deletions were inherited from reportedly normal parents, the deletion in subject 13 from the mother and the deletion in subject 14 from the father. Neither subject nor parent (by report only in 
the case of subject 14) had any hand or foot abnormalities. The presence of these microdeletions in phenotypically normal parents suggests deletion of genes in this interval may not have clinical consequences; at the very least it suggests deletion of the region immediately upstream of the HOXD cluster plays no role in the hand/foot abnormalities. This is in contrast to the report by Svensson et al. [2007] in which the proband had upper- and lowerlimb skeletal anomalies and a deletion of the interval proximal to the HOXD cluster. However, the deletion in subject 12 in our study, who has 4 th/5th toe syndactyly on the right foot, 5th toe brachydactyly on the left foot, and abnormal foot X-rays, supports that deletion of EVX2 and the $5^{\prime}$-end of the HOXD cluster is sufficient to cause at least mild limb anomalies [Goodman et al., 2002]. Thus, our results support the suggestion by Dimitrov et al. [2011] and others that haploinsufficiency of the HOXD cluster, rather than $D L X 1 / D L X 2$, accounts for the skeletal abnormalities in individuals with $2 \mathrm{q} 31.1$ microdeletions.

All probands for whom records were available had a diverse spectrum of neurological deficits, including moderate/severe ID/DD, speech delay, hypotonia, seizures, dysmetria, and/or dystonia. Interestingly, despite the association of hand/foot anomalies with deletions of the region, a comparison of the individuals in our study to those in the literature suggests neurological features and growth delay are the characteristic features associated with 2q31.1 deletions that do not encompass the HOXD cluster. Because these neurological deficits were present in multiple individuals with non-overlapping deletions, regardless of deletion size or interval, multiple genes in the region may play a role in neurodevelopmental processes. This is in contrast to the findings of Mitter et al. [2010] who suggested haploinsufficiency of DLX1/DLX2 and $C H N 1$ may result in the neurological features associated with $2 \mathrm{q} 31.1$ deletions. However, this may also represent an ascertainment bias, because we tested individuals referred for ID/DD.

Although neither $D L X 1 / D L X 2$ are likely to play a role in the limb abnormalities of individuals with 2q31.1 deletions, these genes may play some role in the neurological deficits in these patients. The $D l x$ genes act as modulators of neuron versus oligodendrocyte development in the ventral embryonic forebrain [Petryniak et al., 2007], and both genes are implicated in differentiation and migration of neurons [Cobos et al., 2007; Le et al., 2007]. For example, differentiation and migration of striatal neurons is blocked in Dlx1-null mice, which have late-onset epilepsy [Cobos et al., 2005]. DLX1/DLX2 have also been associated with autism [Laroche et al., 2008; Liu et al.,
2009]. Three individuals with deletions of $D L X 1 / D L X 2$ in this study (subjects 1, 6, and 7) experience seizures and 1 individual has epilepsy (subject 2), but seizures/epilepsy have not been reported in the remaining 5 individuals (subjects 3-5, 8, 9) whose deletions overlap DLX1/DLX2. Furthermore, the deletion in subject 1 extends proximal into 2 q24.3 and removes $S C N 1 A$, deletions of which are associated with severe myoclonic epilepsy in infancy [Dimova et al., 2010; Meisler et al., 2010]. Interestingly, the deletion in subject 9, who does not have seizures, encompasses DLX1/DLX2 and SCN1A, but at 6 months of age this individual may be too young to have developed this feature. In contrast to the findings of Mitter et al. [2010], who suggested haploinsufficiency of $D L X 1 / D L X 2$ may be responsible for seizures associated with $2 \mathrm{q} 31.1$ deletions, the absence of seizure-related phenotypes in 5 of the 7 individuals in our study with deletions of the DLX1/ $D L X 2$ cluster but not $S C N 1 A$ suggests haploinsufficiency of $D L X 1 / D L X 2$ may not result in seizures/epilepsy.

Based on common facial features in 3 of 5 subjects in their study, Dimitrov et al. [2011] suggested a facial gestalt that includes narrow forehead, prominent metopic suture, a small nose with bulbous tip, long and smooth philtrum, downslanting palpebral fissures, thin upper lip, thick and everted lower lip, low-set and dysplastic ears, and micrognathia. The authors proposed a $2.4-\mathrm{Mb}$ critical region for the facial gestalt that begins just distal to $D L X 1 / D L X 2$ and ends just distal to WIPF1. In contrast, Mitter et al. [2010] suggested haploinsufficiency of DLX1/ $D L X 2$ may result in craniofacial dysmorphism associated with 2q31.1 deletions. The individuals in our study have variable dysmorphic features. For example, subject 6, whose deletion encompasses this region, has no reported dysmorphic features, and subject 7 has only microphthalmia. Meanwhile, subject 10, whose deletion lies distal to the proposed critical region, has mild hypotelorism, narrow inner canthal distance, synophrys, bilateral ptosis, downslanting palpebral fissures, and low-set ears. Thus, our study population suggests there may not be a recognizable facial gestalt associated with deletion $2 \mathrm{q} 31.1$ as proposed by Mitter et al. [2010] and Dimitrov et al. [2011].

Likewise, our results suggest that proposed critical regions for several other features present in some individuals with 2q31.1 deletions may not account for the phenotypic variability associated with deletions of this region. For example, Mitter et al. [2010] proposed that haploinsufficiency of SP3 was a promising candidate for cardiac defects, which are occasionally associated with $2 \mathrm{q} 31.1$ deletions. In our study, only 1 individual, subject 10, was reported to have cardiac anomalies. The deletion in this 
subject lies distal to SP3. Likewise, Mitter et al. [2010] suggested disruption of $C H N 1$ as a candidate for the ocular anomalies associated with deletions at $2 \mathrm{q} 31.1$. In our study, 5 subjects $(1,4,7,8$, and 10$)$ were reported to have variable ocular anomalies. Interestingly, there is a $2.8-\mathrm{Mb}$ gap between the distal breakpoint of the deletion in subject 4 and the proximal breakpoint of the deletion in subject 10, and CHN1 lies within this gap. Thus, our results suggest that disruption of multiple genes within $2 \mathrm{q} 31.1$ may be responsible for the variable clinical features associated with deletions of that region.

Our results refine the model proposed by Goodman [2002] and supported by Mitter et al. [2010] and Dimitrov et al. [2011] and suggest that deletions encompassing the HOXD cluster result in hand/foot anomalies of varying severity, including syndactyly, brachydactyly, and ectrodactyly; however, deletions proximal to the HOXD cluster do not appear to result in clinically significant hand/foot anomalies. Specifically, the absence of hand/foot anomalies in any of the individuals with deletions of DLX1/ $D L X 2$ but not the HOXD cluster excludes the region proximal to EVX2/HOXD and implicates the EVX2/HOXD region as a candidate locus for SHFM5.

\section{Acknowledgments}

We thank the subjects and their families for their participation in this study.

\section{References}

Ballif BC, Theisen A, Coppinger J, Gowans GC, Courtens W, Speleman F, Messiaen L, Bormans Hersh JH, et al: Expanding the clinical phenotype of the 3q29 microdeletion syndrome and characterization of the reciprocal $\mathrm{mi}$ croduplication. Mol Cytogenet 1:8 (2008a).

- Ballif BC, Theisen A, McDonald-McGinn DM, Zackai EH, Hersh JH, et al: Identification of a previously unrecognized microdeletion syndrome of 16q11.2q12.2. Clin Genet 74: 469-475 (2008b).

Bejjani BA, Saleki R, Ballif BC, Rorem EA, Sundin K, et al: Use of targeted array-based CGH for the clinical diagnosis of chromosomal imbalance: is less more? Am J Med Genet A 134:259-267 (2005).

-Bijlsma EK, Knegt AC, Bilardo CM, Goodman FR: Increased nuchal translucency and splithand/foot malformation in a fetus with an interstitial deletion of chromosome $2 \mathrm{q}$ that removes the SHFM5 locus. Prenat Diagn 25: 39-44 (2005).

Boles RG, Pober BR, Gibson LH, Willis CR, McGrath J, et al: Deletion of chromosome 2q24q31 causes characteristic digital anomalies: case report and review. Am J Med Genet 55: 155-160 (1995).

-Chinen Y, Tohma T, Izumikawa Y, Iha T, Goya Y, Naritomi K: Small interstitial deletion of the long arm of chromosome 2 (2q24.3): further delineation of $2 \mathrm{q}$ medial monosomy syndrome. Jpn J Hum Genet 41:323-328 (1996).

Cobos I, Calcagnotto ME, Vilaythong AJ, Thwin MT, Noebels JL, et al: Mice lacking DlxI show subtype-specific loss of interneurons, reduced inhibition and epilepsy. Nat Neurosci 8:1059-1068 (2005).

Cobos I, Borello U, Rubenstein JL: Dlx transcription factors promote migration through repression of axon and dendrite growth. Neuron 54:873-888 (2007).
J, Van Roy N, Vamos E: Interstitial deletion 2q33.3-q34 in a boy with a phenotype resembling the Seckel syndrome. Am J Med Genet 71:479-485 (1997).

Del Campo M, Jones MC, Veraksa AN, Curry CJ, Jones KL, et al: Monodactylous limbs and abnormal genitalia are associated with hemizygosity for the human 2q31 region that includes the HOXD cluster. Am J Hum Genet 65:104-110 (1999).

D’Esposito M, Morelli F, Acampora D, Migliaccio E, Simeone A, Boncinelli E: EVX2, a human homeobox gene homologous to the even-skipped segmentation gene, is localized at the $5^{\prime}$ end of HOX4 locus on chromosome 2. Genomics 10:43-50 (1991).

Dimitrov B, Balikova I, de Ravel T, Van Esch H, De Smedt M, et al: 2q31.1 microdeletion syndrome: redefining the associated clinical phenotype. J Med Genet 48:98-104 (2011).

Dimova PS, Yordanova I, Bojinova V, Jordanova A, Kremenski I: Generalized epilepsy with febrile seizures plus: novel SCN1A mutation. Pediatr Neurol 42:137-140 (2010). genesis of split-hand/split-foot malformation. Hum Mol Genet 12 Spec No 1:R51-60 (2003).

Duker AL, Ballif BC, Bawle EV, Person RE, Mahadevan S, et al: Paternally inherited microdeletion at $15 \mathrm{q} 11.2$ confirms a significant role for the SNORD116 C/D box snoRNA cluster in Prader-Willi syndrome. Eur J Hum Genet 18:1196-1201 (2010).

Goodman F, Giovannucci-Uzielli ML, Hall C, Reardon W, Winter R, Scambler P: Deletions in HOXD13 segregate with an identical, novel foot malformation in two unrelated families. Am J Hum Genet 63:992-1000 (1998).
Duijf PH, van Bokhoven H, Brunner HG: Patho-
Goodman FR: Limb malformations and the human HOX genes. Am J Med Genet 112:256265 (2002).

- Goodman FR, Majewski F, Collins AL, Scambler PJ: A 117-kb microdeletion removing HOXD9-HOXD13 and EVX2 causes synpolydactyly. Am J Hum Genet 70:547-555 (2002).

Kan SH, Johnson D, Giele H, Wilkie AO: An acceptor splice site mutation in HOXD13 results in variable hand, but consistent foot malformations. Am J Med Genet A 121A:6974 (2003).

Laroche F, Ramoz N, Leroy S, Fortin C, Rousselot-Paillet B, et al: Polymorphisms of coding trinucleotide repeats of homeogenes in neurodevelopmental psychiatric disorders. Psychiatr Genet 18:295-301 (2008).

Le TN, Du G, Fonseca M, Zhou QP, Wigle JT, Eisenstat DD: Dlx homeobox genes promote cortical interneuron migration from the basal forebrain by direct repression of the semaphorin receptor neuropilin-2. J Biol Chem 282:19071-19081 (2007).

Lezot F, Thomas B, Greene SR, Hotton D, Yuan ZA, et al: Physiological implications of DLX homeoproteins in enamel formation. J Cell Physiol 216:688-697 (2008).

Lezot F, Thomas BL, Blin-Wakkach C, Castaneda B, Bolanos A, et al: Dlx homeobox gene family expression in osteoclasts. J Cell Physiol 223:779-787 (2010).

Li H, Marijanovic I, Kronenberg MS, Erceg I, Stover ML, et al: Expression and function of $D l x$ genes in the osteoblast lineage. Dev Biol 316:458-470 (2008).

Liu X, Novosedlik N, Wang A, Hudson ML, Cohen IL, et al: The DLX1and DLX2 genes and susceptibility to autism spectrum disorders. Eur J Hum Genet 17:228-235 (2009). 
-Maas SM, Hoovers JM, van Seggelen ME, Menzel DM, Hennekam RC: Interstitial deletion of the long arm of chromosome 2: a clinically recognizable microdeletion syndrome? Clin Dysmorphol 9:47-53 (2000).

McConnell TS, Kornfeld M, McClellan G, Aase J: Partial deletion of chromosome 2 mimicking a phenotype of trisomy 18: case report with autopsy. Hum Pathol 11:202-205 (1980).

-Meisler MH, O’Brien JE, Sharkey LM: The sodium channel gene family: epilepsy mutations, gene interactions and modifier effects. J Physiol 588:1841-1848 (2010).

- Mitter D, Chiaie BD, Ludecke HJ, GillessenKaesbach G, Bohring A, et al: Genotypephenotype correlation in eight new patients with a deletion encompassing 2q31.1. Am J Med Genet A 152A:1213-1224 (2010).

- Moller M, Garcia-Cruz D, Rivera H, SanchezCorona J, Cantu JM: Pure monosomy and trisomy 2q24.2-q3105 due to an inv ins $(7 ; 2)$ (q21.2; $3105 q 24.2)$ segregating in four generations. Hum Genet 68:77-86 (1984).

Muragaki Y, Mundlos S, Upton J, Olsen BR: Altered growth and branching patterns in synpolydactyly caused by mutations in HOXD13. Science 272:548-551 (1996).

Nixon J, Oldridge M, Wilkie AO, Smith K: Interstitial deletion of $2 \mathrm{q}$ associated with craniosynostosis, ocular coloboma, and limb abnormalities: cytogenetic and molecular investigation. Am J Med Genet 70:324-327 (1997).
Pescucci C, Caselli R, Grosso S, Mencarelli MA, Mari F, et al: 2q24-q31 deletion: report of a case and review of the literature. Eur J Med Genet 50:21-32 (2007).

Petryniak MA, Potter GB, Rowitch DH, Rubenstein JL: Dlx 1 and Dlx 2 control neuronal versus oligodendroglial cell fate acquisition in the developing forebrain. Neuron 55:417433 (2007).

Qiu M, Bulfone A, Martinez S, Meneses JJ, Shimamura K, et al: Null mutation of $D l x-2$ results in abnormal morphogenesis of proximal first and second branchial arch derivatives and abnormal differentiation in the forebrain. Genes Dev 9:2523-2538 (1995).

Qiu M, Bulfone A, Ghattas I, Meneses JJ, Christensen L, et al: Role of the $D l x$ homeobox genes in proximodistal patterning of the branchial arches: mutations of $D l x-1, D l x-2$, and $D l x-1$ and -2 alter morphogenesis of proximal skeletal and soft tissue structures derived from the first and second arches. Dev Biol 185:165-184 (1997).

Ramer JC, Ladda RL, Frankel CA, Beckford A: A review of phenotype-karyotype correlations in individuals with interstitial deletions of the long arm of chromosome 2. Am J Med Genet 32:359-363 (1989).
Shabtai F, Klar D, Halbrecht I: Partial monosomy of chromosome 2. Delineable syndrome of deletion 2 (q23-q31). Ann Genet 25:156158 (1982).

Slavotinek A, Schwarz C, Getty JF, Stecko O, Goodman F, Kingston H: Two cases with interstitial deletions of chromosome 2 and sex reversal in one. Am J Med Genet 86:75-81 (1999).

Svensson AM, Curry CJ, South ST, Whitby H, Maxwell TM, et al: Detection of a de novo interstitial 2q microdeletion by CGH microarray analysis in a patient with limb malformations, microcephaly and mental retardation. Am J Med Genet A 143A:1348-1353 (2007).

Traylor RN, Fan Z, Hudson B, Rosenfeld JA, Shaffer LG, Torchia BS, et al: Microdeletion of 6q16.1 encompassing EPHA7 in a child with mild neurological abnormalities and dysmorphic features: case report. Mol Cytogenet 2:17 (2009).

Wamsler C, Muller B, Freyberger G, Schmid M: Interstitial deletion $\operatorname{del}(2)(\mathrm{q} 24 \mathrm{q} 31)$ with a phenotype similar to $\operatorname{del}(2)(\mathrm{q} 31 \mathrm{q} 33)$. Am J Med Genet 39:204-206 (1991).

Zhao X, Sun M, Zhao J, Leyva JA, Zhu H, et al: Mutations in HOXD13 underlie syndactyly type $\mathrm{V}$ and a novel brachydactyly-syndactyly syndrome. Am J Hum Genet 80:361-371 (2007). 